\title{
PERAN RESERSE DALAM PENYIDIKAN TINDAK PIDANA PENCURIAN DENGAN PEMBERATAN (Studi Kasus Polsek Sukawati, Gianyar. Bali)
}

\author{
Kadek Bayu Krisna Juliantara, Anak Agung Sagung Laksmi Dewi, I Made Minggu Widyantara \\ Fakultas Hukum Universitas Warmadewa, Denpasar-Bali, Indonesia \\ Krisnajuliantara0707@gmail.com, laksmidewii29@gmail.com, mademinggu21@gmail.com
}

\begin{abstract}
Abstrak
Belakangan ini semakin meningkat terjadinya tindak pidana terhadap pencurian dengan pemberatan maka Reserse dalam menangani kasus ini harus teliti dalam mengungkap tindak pidana pencurian dengan pemberatan. Penelitian ini bertujuan untuk mengakaji peran reserse dalam mengungkap tindak pidana pencurian dengan pemberatan dan menganalisis hambatan-hambatan reserse dalam menngungkap tindak pidana pencurian dengan pemberatan. Tipe penelitian yang di gunakan adalah empiris yaitu penelitian berdasarkan fakta yang terjadi serta mengembangkan konsep yang ada, metode pendekatan yang digunakan adalah dengan cara melakukan penelitian dilapangan. Adapun sumber bahan hukum yang digunakan adalah bahan hukum primer dan sekunder yang dperoleh melalui observasi dan dokumentasi. Setelah seluruh data terkumpul, maka selanjutnya adalah melakukan diolah dan dianalisis secara kualitatif. Hasil penelitian menunjukkan bahwa Peran penyidik reserse kriminal Polsek Sukawati dalam mengungkap tindak pidana pencurian pemberatan dimulai dengan adanya laporan pengaduan dari masyarakat selanjutnya tindakan Reserse Polsek Sukawati melakukan Pemeriksaan ditempat kejadian perkara, Pemeriksaan Saksi-Saksi, Penyitaan Barang Bukti, Penangkapan, Penggeledahan, Penahanan, Pemberkasan dan penyerahan berkas pekara kepada ke pengadilan. Hambatan yang dihadapi unit Reserse Kriminal Sektor Sukawati ialah Pelaku Seorang Residivis, kurangnya alat untuk melacak pelaku, faktor masyarakat.
\end{abstract}

Kata Kunci : Reserse, Penyidikan, Tindak Pidana Pencurian Pemberatan

\begin{abstract}
Recently, the incidence of criminal acts of theft with weights has increased, the investigator in handling this case must be careful in uncovering criminal acts of theft with weights. This study aims to examine the role of the detective in uncovering the crime of theft by weighting and analyzing the obstacles of the investigator in uncovering the crime of theft by weight. The type of research used is empirical, namely research based on facts that occur and develop existing concepts, the approach method used is by conducting research in the field. The sources of legal materials used are primary and secondary legal materials obtained through observation and documentation. After all the data has been collected, the next step is to process and analyze it qualitatively. The results showed that the role of the criminal investigator of the Sukawati Police in uncovering the criminal act of theft of weighting began with a complaint report from the public, then the action of the Sukawati Police Detective carried out an examination at the scene of the case, examination of witnesses, confiscation of evidence, arrest, search, detention, filing. and submission of case files to the court. The obstacles faced by the Criminal Investigation Unit of the Sukawati Sector are the perpetrator, a recidivist, the lack of tools to track the perpetrators, and community factors.
\end{abstract}

Keywords: Investigation, Investigation, Criminal Act of theft Weighting

\section{PENDAHULUAN}

Dasar Negara Republik Indonesia ialah Panca sila yang dimana diatur dalam Pasal 1 Ayat (3) UUD Negara Republik Indonesia 1945 menyebutkan bahwa Negara Inonesia adalah Negara Hukum. Maka dari itu Negara Indonesia adalah Negara yang berdasarkan atas Hukum (rechstaat), tidak berdasarkan kekuasaan belaka (mechstaat). Hal ini mengandung pengertian bahwa Negara (termasuk didalamnya segala perangkat pemerintah dan lembaga-lembaga) dalam melaksanakaan tindakan apapun harus dilandasi oleh hukum dan dapat dipertanggung jawabkan secara hukum (Kadir, 2004).

Tindak kejahatan dan kriminalitas semakin tinggi mengikuti pertumbuhan ekonomi yang cukup berkembang (Purwanti \& Widyaningsih, 2019). Hal ini bisa dilihat dari media cetak maupun 
eloktronik seperti Tv maupun radio yang memberikan informasi mengenai tindakan kejahatan yang ada di tanah air, mulai dari tindakan kekerasan, penipuan, hingga pencurian. Akhir-akhir ini, banyak terjadi tindak pidana terhadap pencurian dengan pemberatan dan tentunya banyak menarik perhatian masyarakat dimana telah diketahui dalam kitab Undang-undang hukum pidana (KUHP) telah ditentukan mengatur tentang perbuatan-perbuatankejahatan dan pelanggaran. Pebuatan pidana atau delik,artinya Perbuatan yang oleh hukum pidana dilarang dan diancam dengan pidana (Moeljatno, 2002). Pencurian dengan pemberatan diatur dalam pasal 363 KUHP dengan pidana penjara paling lama 7 tahun penjara. Kepolisian yang bertugas untuk melakukan proses penyidikan terhadap tindak pidana pencurian dengan pemberatan disebut Reserse Kriminal (Reskrim)

Penelitian terdahulu mengungkapkan bahwa ada dua faktor penghambat aparat kepolisian dalam hal mengungkap tindak kejahatan yaitu faktor interna meiputi yaitu kesungguhan masyarakat kepolisian itu sendiri selanjutnya faktor eksternal yaitu kurangnya personi kepolisian (Brahmantara et al., 2020). Terdapat sikap controversial dalam menanggapi kemunculan kejahatan ini karena terdapat bentuk kejahatan ini yang dilakukan karena terpaksa demi memenuhi kebutuhan, sehingga para pelaku itu tidak penuh melakukan tindakan kejahatan tersebut (Paternoster \& Bushway, 2001), (David \& Kenneth. C, 2001). Sekalipun penelitian ini sudah banyak dilakukan penelitian sebelumnya namun sampai saat ini, masih terdapat masalah pencurian, berdasarkan hal itu ingin melakukan penelitian dari kajian yang berbeda dengan tujuan untuk mengakaji peran reserse dalam mengungkap tindak pidana pencurian dengan pemberatan dan menganalisis hambatan-hambatan reserse dalam menngungkap tindak pidana pencurian dengan pemberatan

\section{METODE PENELITIAN}

Penelitian ini didesain mennggunakan penelitian empiris yaitu berdasarkan kenyataan atau fakta yang terjadi serta mengembangkan konsep yang ada. Sedangkan metode pendekatan yang digunakan adalah pendekatan yang dilakukan dengan cara melakukan penelitian dilapangan. Penelitian ini mengambil lokasi di Polsek Sukawati, Gianyar. Bali. Alasan peneliti memilih lokasi tersebut karena tindak kejahatan pencurian pemberatan masih banyak ditemukan didaerah Sukawati. Adapun Sumber dan data dalam penelitian ini yaitu, sumber data primer dan sumber data sekunder. Teknik Pengumpulan datanya adalah untuk data primer dikumpulkan melalui observasi dan wawancara dengan informan. Sedangkan data sekunder dikumpulkan dengan teknik pencatatan-pencatatan yang diperoleh dengan membaca Undang-undang yang berkaitan dengan permasalahan, disamping itu bersumber dari kepustakaan, jurnal-jurnal hukum,hasil penelitian dan media elektronik (internet). Setelah seluruh data terkumpul, maka selanjutnya adalah melakukan diolah dan dianalisis secara kualitatif yaitu menganalisa data berdasarkan kualitas lalu dideskripsikan dengan menggunakan katakata sehingga diperoleh bahasa atau paparan dalam bentuk kalimat yang sistematis dan dimengerti (Moleong, 2005).

\section{HASIL DAN PEMBAHASAN}

\section{Peran Reserse dalam Mengungkap Tindak Pidana Pencurian Pemberatan}

Kepolisian Sektor Sukawati adalah bagian dari Kepolisian Republik Indonesia, perannya didalam mengungkap tindak pidana pencurian pemberatan tidak terlepas dari kehidupan masyarakat. bagian yang tidak pernah terlepas dari lingkungan masyarakat yaitu Kepolisian Sektor Sukawati ialah Unit Reserse Kriminal Polisi Sektor Sukawati. Berdasarkan wawancara Kepala Unit (Kanit) Reserse Kriminal Polisi Sektor Sukawati pelaksanaan tindakan penyelidikan Reserse dimulai dengan adanya laporan pengaduan ataupun informasi pengaduan dari masyarakat untuk dilakukan Penyelidikan selanjutnya ditingkatkan menjadi penyidikan guna mengetahui apakah peristiwa tersebut merupakan peristiwa pidana atau bukan (Wawancara Tanggal 18 Maret 2020). setelah menerima laporan atau pengaduan dari masyarakat Reserse lalu melakukan penelitian laporan atau pengaduan tentang peristiwa yang diduga tindak pidana untuk memperoleh tentang:

1. Apakah yang terjadi

2. Dimana terjadi

3. Bilamana terjadi

4. Siapa yang terlibat atau bersangkutan

5. Dengan apa yang dilakukan 


\section{Bagaimana terjadi}

7. Mengapa dilakukan

Maka dari itu Kepolisian Sektor Sukawati menurunkan anggotanya kedalam masyarakat untuk mengumpulkan bukti-bukti dan kebenaran yang berkaitan dengan kasus yang sudah diterima. Jika sudah selesai melakukan penyelidikan setelah itu Unit Reserse Kriminal akan melakukan penyidikan. Berdasarakkan hasil wawancara pada tanggal 18 Maret 2020 kepada Kanit, mengungkapkan Ada beberapa tindakan yang dikerjakan Satuan penyidik Unit Reserse Kriminal didalam mengusut tindak pidana pencurian pemberatan yaitu:

1. Pemeriksaan ditempat kejadian perkara

Tempat kejadian perkara ialah sumber keterangan yang sangat penting untuk mengumpulkan bukti yang kuat guna mengungkapkan suatu kejadian tindak pidana. Di dalam melaksanakan Pengolahan Tempat Kejadian Perkara (TKP) kasus pencurian pemberatan. Unit Reserse Kriminal Polsek Sukawati melibatkan tiga orang penyidiknya untuk melakukan penyidikan

2. Pemeriksaan Saksi-Saksi

Pemeriksaan saksi adalah sebagai salah satu kegiatan penindakan dalam rangka penyidikan tindak pidana dimaksudkan untuk menghadirkan saksi kedepan penyidik guna diadakan pemeriksaan dalam rangka memperoleh keterangan-keterangan dan petunjuk-petunjuk mengenai tindak pidana yang terjadi. Dalam mencari saksi, penyidik mendatangi orang yang berhubungan langsung dengan korban, yang pada saat itu berada di Tempat Kejadian Perkara (TKP).

3. Penyitaan Barang Bukti

Penyitaan barang bukti merupakan salah satu kegiatan penindakan dalam rangka penyidikan tindak pidana. Barang-barang yang berhubungan dengan dilakukannya suatu tindak pidana pencurian akan disita dan dijadikan sebagai barang bukti yang kuat

4. Penangkapan tersangka

Secara Umum Penangkapan merupakan salah satu kegiatan penindakan dalam rangka penyidikan tindak pidana. Jika barang bukti dan saksi sudah terkumpul barulah dilakukan penangkapan tersangka oleh penyidik Unit Reserse Kriminal Sektor Sukawati yang sudah diketahui identitas pelaku tindak pidana.

5. Penggeledahan

Penggeledahan merupakan salah satu kegiatan penindakan dalam rangka penyidikan tindak pidana untuk menemukan barang bukti dan tersangka pelaku tindak pidana. Penggeledahan dilakukan untuk mencari atau menemukan barang apa saja yang dipergunakan tersangka saat melakukan tindak pidana pencurian pemberatan.

6. Penahanan

Secara Umum Penahanan merupakan salah satu kegiatan penindakan dalam rangka penyidikan tindak pidana. Dasar dilakukan penahanan setelah mendapatkan bukti yang cukup untuk melakukan penahanan, kewenangan Reserse melakukan penahanan terhadap tersangka pelaku tindak pidana adalah 20 hari, selanjutnya diperpanjang 40 hari atas dasar surat perpanjangan penahanan dari penuntut umum Kejaksaan Negeri.

7. Pemberkasan dan penyerahan berkas pekara

Penyerahan berkas perkara adalah tindakan penyidik untuk menyerahkan berkas pekara dan menyerahkan tanggung jawab atas tersangka serta barang bukti kepada kejaksaan atau ke pengadilan dalam hal acara pemeriksaan cepat atas kuasa penuntut umum demi hukum, sesuai dengan ketentuan peraturan perundang-undangan yang berlaku, jika barang bukti dan saksi-saksi sudah lengkap maka kegiatan penyerahan berkas pekara merupakan akhir dari proses penyidikan tindak pidana.

\section{Faktor-Faktor Penghambat Reserse dalam Mengungkap Tindak Pidana Pencurian dengan Pemberatan}

Kepolisian didalam melaksanakan tugas dan wewenangnya diharuskan melaksanakan tugasnya sesuai dengan aturan hukum yang berlaku, didalam mengungkapkan suatu kejadian tindak pidana pencurian dengan pemberatan pastinya terdapat hambatan didalam melaksanakan tugasnya. Hambatan yang diterima Reserse Kriminal Sektor Sukawati didalam mengungkapkan tindak pidana pencurian pemberatan ialah:

a. Pelaku Seorang Residivis 
Residivis didalam Kamus hukum disebut dengan "Recidivie" yang memiliki arti pengulangan melakukan tindak pidana. Orang yang mengulangi melakukan tindak pidana disebut "Recidivist". Menurut kamus hukum rescidivist adalah seseorang yang telah berulang lagi melakukan tindak pidana dan untuk recidivie hukumnya diperbuat dengan ditambah sepertiganya (J. C. T. Simorangkir, 2008)

Residivis adalah suatu pengulangan tindak pidana atau melakukan kembali kriminal yang sebelumnya biasa dilakukan setelah dijatuhi hukuman pidana dan menjalani penghukumannnya (Hairi, 2018). Residivis adalah apabila seseorang melakukan suatu tindak pidana dan untuk dijatuhkan pidana padanya, akan tetapi dalam jangka waktu tertentu:

1. Setelah pidana tersebut dilaksanakan seluruhnya atau sebagian,

2. Sejak pidana tersebut dihapuskan,

3. Apabila kewajiban menjalankan pidana itu belum kadarluasa (Kanter \& Sianturi, 2002).

Pelaku seorang Residivis adalah suatu kendala yang dihadapi Reserse Kriminal Polsek sukawati karena seseorang tersebut sebelumnya sudah dijatuhi hukuman yang sama namun kembali lagi melakukan kejahatan pidana yang sama sehingga pelaku Residivis lebih pintar dalam melakukan kejahatan lagi maka tantangan dari pihak kepolisian harus lebih pintar dan professional dalam menghadapi seorang Pelaku Residivis (Wawancara dengan IPTU I Ketut Artika,Tanggal 18 Maret 2020).

b. Kurangnya alat untuk melacak pelaku tindak pidana pencurian pemberatan

Salah satu kurangnya alat dari Reserse Kriminal Polsek Sukawati ialah alat Tracking jika pelaku tindak pidana tidak mempunyai e-ktp dimana alat tracking tersebut bisa dipergunakan untuk melacak keberadaan seseorang yang telah melakukan suatu Tindak Pidana, sehingga dapat menghambat proses penyelidikan maka diperlukan alat yang memadai agar suatu kasus Tindak Pidana dapat ditangani dengan cepat dan tepat (Wawancara dengan IPTU I Ketut Artika,Tanggal 18 Maret 2020).

c. Faktor masyarakat

Salah satu penegak Hukum berasal dari masyarakat dan bertujuan untuk mencapai kedamaian, setiap warga msayarakat atau kelompok sedikit banyaknya mempunyai kesadaran hukum, dimana masyarakat sangat berperan penting dalam membantu pihak aparat Negara dalam mengungkap suatu tindak pidana. Faktor masyarakat juga menjadi kendala yang dialami Reserse Kriminal Sektor Sukawati yang diantaranya ialah kurangnya kewaspadaan masyarakat terhadap lingkungan tempat tinggal mereka dan masyarakat yang menjadi korban terkadang tidak jujur dalam menyampaikan permasalah yang dihadapi kepada pihak penyidik.

d. Faktor cuaca

Faktor cuaca juga menjadi salah satu kendala yang dihadapi oleh pihak penyidik Kepolisian Sektor Sukawati dalam mengungkap Tindak Pidana Pencurian dengan pemberatan, contohnya saat cuaca hujan penyidik kesulitan menemukan sidik jari pelaku karena sudah rusak saat diidentifikasi.

e. Faktor personil penyidik

Petugas penyidik saat melakukan proses pengolahan Tempat Kejadian Perkara (TKP) kurang teliti atau tidak perfesional dalam melakukan pengolahan tempat kejadian perkara sehingga tidak efektif dalam pengolahan tempat kejadian perkara.

\section{SIMPULAN DAN SARAN}

\section{Simpulan}

Berdasarkan uraian dapat menarik simpulan bahwa Peran penyidik reserse kriminal kepolisian Sektor Sukawati didalam mengungkapkan tindak pidana pencurian dengan pemberatan, Reserse Kriminal Polisi Sektor Sukawati pelaksanaan tindakan penyelidikan Reserse dimulai dengan adanya laporan pengaduan ataupun informasi pengaduan dari masyarakat untuk dilakukan penyidikan guna mengetahui apakah peristiwa tersebut merupakan peristiwa pidana atau bukan, selanjutnya tindakan yang dilakukan Reserse Sektor Sukawati adalah sebagai berikut : Pemeriksaan ditempat kejadian perkara, Pemeriksaan Saksi-Saksi, Penyitaan Barang Bukti, Penangkapan tersangka, Penggeledahan, Penahanan, Pemberkasan dan penyerahan berkas pekara kepada kepada kejaksaan atau ke pengadilan. Hambatan yang dialami unit Reserse Kriminal Sektor Sukawati didalam mengungkapkan tindak pidana pencurian pemberatan ada dua yaitu faktor internal yaitu kurangnya alat untuk melacak pelaku Tindak Pidana Pencurian Pemberatan seperti alat tracking bisa dipergunakan untuk melacak keberadaan seseorang yang telah melakukan suatu Tindak Pidana. Personil Penyidik saat melakukan proses pengolahan Tempat Kejadian Perkara (TKP) kurang teliti atau tidak perfesional dalam 
melakukan pengolahan tempat kejadian perkara. Faktor eksternal Pelaku seorang Residivis adalah suatu kendala yang dihadapi Reserse Kriminal Polsek sukawati karena seseorang tersebut sebelumnya sudah dijatuhi hukuman yang sama namun kembali lagi melakukan kejahatan pidana yang sama, Kurangnya kewaspadaan masyarakat terhadap lingkungan tempat tinggal mereka. Faktor cuaca juga menjadi salah satu kendala yang dihadapi oleh pihak penyidik Kepolisian Sektor Sukawati dalam mengungkapkan Tindak Pidana Pencurian dengan pemberatan.

\section{Saran}

Dari hasil penelitian ini, adapun saran yaitu diharapkan kepada Reserse Kriminal Polsek untuk memberikan penyuluhan kepada masyarakat guna meningkatkan kewaspadaan masyarakat terhadap tindak pidana pencurian pemberatan. Diharapkan agar pihak kepolisian melakukan upaya preventif ( patroli ) di wilayah hukum Polsek Sukawati demi terciptanya keamanan dan ketertiban di wilayah Sukawati, apalagi di masa pandemi seperti ini kemungkinan bisa terjadi Tindak pidana pencurian dengan pemberatan akibat terdesaknya kebutuhan hidup guna menyambung hidup, karena di situasi pandemi seperti ini banyak yang kehilangan pekerjaan (PHK). Disini peran Reserse sangat diharapkan untuk menjaga agar tidak terjadinya hal yang tidak diinginkan di wilayah hukum Polsek Sukawati.

\section{DAFTAR PUSTAKA}

Brahmantara, I. G. N. A., Dewi, A. A. S. L., \& Karma, N. M. S. (2020). Peranana Reserse Kriminal dalam Mengungkap Tindak Pidana Pencurian Kendaraan Bermotor di Wilayah Hukum Polsek Ubud. Jurnal Pereferensi Hukum, 1(1), 14-20.

D, C., \& K.C, L. (2001). Unemployment and Crime Rate Fluctuations. Journal of Quantitative Criminology, 17(4), 329-342.

Hairi, P. J. (2018). Konsep dan Pembaruan Residivisme dalam Hukum Pidana di Indonesia. Negara Hukum, 9(2), 199-216.

J. C. T. Simorangkir. (2008). Kamus Hukum. Jakarta. Sinar Grafika.

Kadir, A. (2004). Hukum dan Penelitian Hukum. PT Citra Aditya Bakti.

Kanter, E. Y., \& Sianturi, S. R. (2002). Asas-asas Hukum Pidana di Indonesia dan Penerapannya. Jakarta. Storia Grafika.

Moeljatno. (2002). Asas-Asas Hukum Pidana. Jakarta. Rineka Cipta.

Moleong, L. J. (2005). Metode Penelitian Kualitatif. Remaja Rosdakarya.

Paternoster, R., \& Bushway. (2001). Theoretical and Empirical Work on the Relationship between Unempl. Journal of Quantitative Criminology, 17(4), 391-407.

Purwanti, E. Y., \& Widyaningsih, E. (2019). Analisis Faktor Ekonomi yang Mempengaruhi Kriminalitas di Jawa Timur. Jurnal Ekonomi-QU, 9(2), 154-177. 